Kucheriavyi V.P. (2005). Ozelenennia naselenykh mists. Lviv: Svit. 456 s. [in Ukrainian].

Radishchev, A. P. (1972). Rododendrony v sadovoi kulture. Moskva: Izd-vo Moskovskogo universiteta. $68 \mathrm{~s}$. (in Russian).

Tymchyshyn, H. V. (2003). Biolohiia ta osoblyvosti kul'tury rododendroniv (Rhododendron L.) na Zakhidnomu Podilli: avtoref. dys. na zdobuttia nauk. stup. kand. biol. nauk: spetsial'nist'. 03.00.05 «Botanika». Kyiv. 17 s. (in Ukrainian).

Tymchyshyn, H. V. (2003). Rododendrony ta ikh vyroschuvannia (praktychni rekomendatsii). Kyiv. 16 s. (in Ukrainian).

Shumyk, M. I. (2012). Landshaftno-ekolohichnyj pryntsyp stvorennia ekspozytsijnoi kolektsii roslyn rodyny Ericaceae Juss. ex situ. Visti biosfernoho zapovidnyka «Askaniia - Nova»: naukovyj zhurnal. № 14. C. 413-418. (in Ukrainian).

Dostalkova, A. (1981). Rhododendrony. Praga.157 s.

Rehder, A. (1949). Manual of cultivated trees and shrubs. New York: The Macmillan company. 996 p.

УДК 581.6

\title{
Декоративні властивості представників роду Hydrangea L. у Правобережному Лісостепу України
}

Альона В. Гончарова

Наџіональний дендрологічний парк «Софіївка» НАН України, Черкаська обл., Україна, e-mail: ukrcargo@ukr.net ORCID ID0000-0001-6218-4691

\section{Реферат.}

Mema. Рід Hydrangea L. належить до родини Гортензієві (Hydrangeaceae Dumort.), яка об’єднує 19 родів і 260 видів деревних та оранжерейних рослин, поширених в помірній і субтропічній зонах Північної півкулі, головним чином у Північній Америџі та Східній Азії (Китай, Японія). Рослини роду Hydrangeа широко використовують в зеленому будівниџтві, проте їхі декоративні властивості є недостатньо дослідженими. Тому мета нашої роботи полягала у визначенні декоративних властивостей представників роду Hydrangea за інтродукџї у Правобережному Лісостепу України. Методи. В умовах НДП «Софіївка» обстежено насадження представників роду Hydrangea. За методикою Н. В. Котелової та О. Н Виноградової в модифікаџї І. В. Таран, А. М. Агапової оџінювали декоративність рослин досліджуваних видів, зокрема квіток, пагонів, листків та загальну декоративність

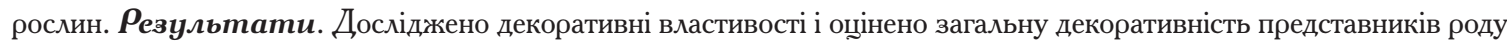
Hydrangea. Визначено перспективи їх використання в озелененні та створенні ландшафтних композиџій. Завдяки довготривалому џвітінню та зміні забарвлення листків і суџвіть впродовж вегетаџії, можливе також використання ïx у вертикальному озелененні та для декораџії берегів водойм, зміџнення схилів, а також як грунтопокривних рослин під кронами дерев. Наведено характеристику декоративних властивостей представників роду Hydrangea в дендрологічному парку «Софіївка» НАН України.

Ключові слова: Hydrangeaceае, декоративність, џвітіння, ландшафтні композиџії. 


\title{
Decorative Qualities of Hydrangea L. Genus Representatives in the Right-Bank Forest- steppe of Ukraine
}

\author{
Aliona V. Goncharova \\ National Dendrological Park «Sofiyivka» of the National Academy of Sciences of Ukraine, Cherkasy region, Ukraine, \\ e-mail: ukrcargo@ukr.net \\ ORCID ID 0000-0001-6218-4691
}

\begin{abstract}
.
Aims. Hydrangea L. genus is represented by 35 species of plants distributed in the temperate and subtropical zones of the Northern Hemisphere mainly in North America and East Asia (China, Japan). The plants of Hydrangea genus are widely introduced in landscape design nonetheless their decorative qualities have been insufficiently studied. Therefore,

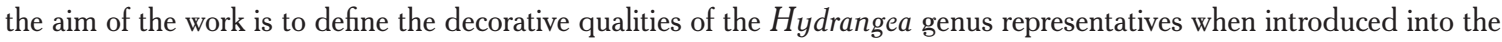
Right- Bank forest-steppe of Ukraine. Methods. The planting of Hydrangea genus representatives has been investigated in the NDP «Sofiyivka». The decorative qualities of the studied plants species, including flowers, shoots, leaves, and the general decorative nature of plants evaluated by the methods of N. V. Kotelova and O. N. Vynogradov in modification of I. V. Taran and A. M. Agapova. Results. The decorative qualities of Hydrangea genus have been studied and its general decorativeness has been evaluated. The prospects of their use in the greenery and creation of landscape compositions have been revealed. Due to the peculiarities of flowering and changes in coloration of leaves and inflorescences during the vegetation period, the Hydrangea decorativeness is kept during a long time. It is also possible to use them in vertical greening as well as for decorating the shores of the reservoirs, strengthening the slopes and as groundcover plants under the trees' crowns. The characteristics of the decorative peculiarities of the Hydrangea genus representatives in the dendrological park «Sofiyivka» have been presented.
\end{abstract}

Key words: Hydrangea, decorative, flowering, landscape compositions.

Вступ/Introduction. Важливу роль у формуванні ландшафту парку та присадибної ділянки відіграє вміле поєднання рослин: однорічників, багаторічників, кущів і дерев з різноманітними листками і суџвіттями. ФОрма та забарвлення рослини може змінюватись залежно від пори року та умов росту. Куші, висота яких може досягати до трьох метрів і вище, можуть рости у групових композиџіях, як солітери, а також прикрашати присадибні ділянки.

Для того шоб озеленення найповніше відповідало різним вимогам, при підборі рослин необхідно врахувати їх декоративні властивості: висоту, забарвлення та форму листків як під час вегетаџї, так і восени (Muzyka, 2002).

Для оџінки загального декоративного вигляду рослин, в умовах інтродукџї, необхідна обов’ язкова оџінка декоративних властивостей окремих органів, зокрема: форма крони, форма і забарвлення суџвіть, листків та пагонів.

Рослини з роду Hydrangea - надзвичайно декоративні рослини, які в садівниџтві џіняться за різноманітність забарвлень і форм суџвіть. Рослина з великими та дрібними суџвіттями, з листками різної форми і квітками всіх можливих забарвлень від блідо-фіолетового до аквамаринового, від рожевого до темно-червоного забарвлення. Рясне џвітіння гортензії надає ділянџі оригінального та незвичного вигляду. Особливістю квітки є іiї розташування в шиткоподібних або волотевих џимозних суџвіттях. Квітки мають біле, блакитне та рожеве забарвлення. Bсі представники роду Hydrangea ентомофільні рослини.

Під час проектування і створення міських зелених насаджень, а також шодо їх утримання розроблено методичні рекомендаџї для місџевого самоврядування шодо ефективного таксономічного підбору деревних рослин.

Зокрема вказується, шо для посилення фітомеліоративної ролі вуличних зелених насаджень доџільно висаджувати більше кущів, таких як гортензія великолиста - H. macrophylla DC. та гортензія деревоподібна - H. arborescens L., особливо в смузі між тротуаром і проїжджою частиною, H. petiolaris Siebold (гортензія черешкова) входить у групу дуже џінних рослин, які використовують для вертикального озеленення. За допомогою численних повітряних 
коренів і присосок, ліана може обплести будь-яку опору своїми гнучкими пагонами з красивим і рясним џвітінням. Так, в умовах Києва, на ділянках з недостатнім зволоженням, Hydrangea використовували для вертикального озеленення. Не менш џінними гортензії є як грунтопокривні рослини, при висаджуванні на добре зволожених місџях.

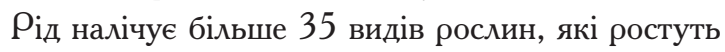
у Східній та Південній Азії, Північній та Південній Америџі, найбільше видів поширені у Китаї та Японї.

До Європи, рослини роду Hydrangea, потрапили з Японії у XVII ст. і настільки вразили своїми формами та квітуванням, шо у XIX ст. почалася інтенсивна робота з селекціонування гортензій у Франџії, Німеччині та Великобританії. До 60 років XX століття було виведено більше 100 сортів (Miller, Renee, 2018).

До 50-х років минулого століття види роду $\mathrm{Hy}$ drangea не набули поширення. Як описує Є. М. Фомін, (1969) у своїи книзі «Гортензии», найпопулярнішою Hydrangea була серед декоративних рослин

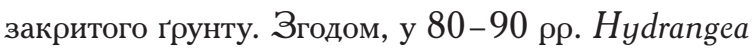
почала набувати популярності у колекџіях ботанічних садів, дендропарків України (Kataloh,1987) та приватних ділянок.

Mатеріали і методи/Materials and Methodology. Дослідження проводили у НДП «Софіївка» НАН України впродовж 2015-2017 рр.

Об'єкт досліджень - декоративна оџінка представників виду Hydrangea L. в умовах інтродукџї.

Предмет досліджень - види та внутрішньовидові таксони роду Hydrangea: H. macrophylla (Thunb.) 'Lanarth White', 'Blaumeise', H. petiolaris Sieb. et Zucc, H. quercifolia Bartr., H. arborescens L., H. cinerea Small, H. serrata (Thunb.). Для визначення декоративності рослин використовували методику Н.В. Котелової та О.Н. Виноградової (Kotelova, 1974) в модифікаџії І. В. Таран, А. М. Агапової (Taran, 1981). Декоративні властивості інтродуџентів оџінювали шомісяџя за такими ознаками: архітектоніка крони і стовбура $\left(\mathrm{A}_{1}\right)$, формою та забарвленням листків $\left(\mathrm{A}_{2}\right)$, декоративністю суџвіть, квіток $\left(\mathrm{A}_{3}\right)$; плодів $\left(\mathrm{A}_{4}\right)$; забарвленням та фактурою кори, гілок, пагонів $\left(\mathrm{A}_{5}\right)$.

Декоративну оџінку проводили за 5-бальною шкалою, та визначали за формулою:
$\mathrm{P}_{\mathrm{cp}}=\frac{\mathrm{P}_{1} \times \mathrm{A}_{1}+\mathrm{P}_{2} \times \mathrm{A}_{2}+\mathrm{P}_{3} \times \mathrm{A}_{3}+\mathrm{P}_{4} \times \mathrm{A}_{4}+\mathrm{P}_{5} \times \mathrm{A}_{5}}{\mathrm{P}_{1}+\mathrm{P}_{2}+\mathrm{P}_{3}+\mathrm{P}_{4}+\mathrm{P}_{5}}$

де $\rho_{1}, \rho_{2} \ldots \rho_{5}-$ перевідні коефіџієнти, (для архітектоніки крони $\rho_{1}=4$, для листків $\rho_{2}=3$, для квіток $\rho_{3}=2$, для плодів $\rho_{4}=2$, для фактури і забарвленням кори $\rho_{5}=1$.

Результати та обговорення/Results and Discussion. Важливою ознакою, при оџінюванні декоративності рослин має архітектоніка стовбура та крони, оскільки вона сприймається впродовж року, а в осінньо-зимовий період має виразні властивості. Починаючи з весняного періоду всі види візуально оџінені у п'ять балів - $\left(\mathrm{A}_{1}=5\right)$, окрім $H$. petiolaris Sieb. et Zucc. $\left(\mathrm{A}_{1}=4\right)$.

У формуванні загального декоративного вигляду кущів першочергове значення належить листкам, а саме іх забарвленню, формі, розмірам та тривалості періоду облиствлення впродовж вегетаџійного періоду (Gromadin, 2009). За формою лист ки видів роду Hydrangea різноманітні та виразні, овальні, великі, завдовжки 10-20 см, завширшки 7-12 см з гострою верхівкою і злегка помітним жилкуванням.

H. macrophylla (Thunb.) має широкояйџеподібні великі листки, завдовжки 8-15 см, завширшки 5-7 см зверху темно-зелені, блискучі, з великими зубчиками. Існують декоративні форми з строкатими листками (H. macrophylla 'Variegata'). Не менш џікавим є вид $H$. petiolaris Sieb. et Zucc. у якого листки широкояйџеподібні, довгочерешкові, гладенькі, з дрібнозубчастим краєм.

H. quercifolia куш, з яскраво вираженими листками та квітками. Аистки жовтувато-зелені до темнозелених зверху, та сріблясто-білі знизу. Мають по три, п'ять, або сім гострих часток, за формою подібні до дубових листків. Восени листки багаті червоними, бронзовими та фіолетовими відтінками. Протягом вегетаџї візуальне оџінювання виду $H$. quercifolia Bartr. становило $-\widehat{A}_{3}=5$, а $\rho_{c \rho}=4$ бали. Окрім основного забарвлення листків спостерігається значна його зміна протягом вегетаџіі. Деякі сорти зокрема, H. macrophylla (Thunb.) 'Lanarth White' може змінювати забарвлення листків восени на багряні. При розпусканні та впродовж весняно-літнього періоду листки видів Hydrangea (H. arborescens, H. macrophylla, H. cinerea, H. paniculata, H. serrata, H. petiolaris) мають декоративний вигляд і тому оџінені у п'ять балів - $\left(\mathrm{A}_{2}=5\right)$. 
При підборі видів для ландшафтно-паркових насаджень вирішальним елементом $є$ џвітіння рослини. В залежності від погодних умов початок џвітіння ми спостерігали в кінџі травня - початку червня (23.05-8.06). Џвітіння Hydrangea триває близько 40-45 діб, а H. paniculata має довготривале џвітіння до 90-120 діб. Декоративна џінність квіток визначається їх формою, розмірами та забарвленням.

Висока џінність гортензій зумовлена такими вагомими декоративними ознаками як форма, шільність та забарвлення суџвіть. За формою та будовою суџвіть види Hydrangea поділяють на кулясті (H. arborescens, H. macrophylla), зонтичні (H. serrata, H. petiolaris, H. macrophylla), конусоподібні (H. paniculata, H. quercifolia). Забарвлення квіток відіграє важливу роль в ї естетичному сприйнятті (Korkulenko, 2012). Суџвіття Hydrangea мають як фертильні так і стерильні квітки. У більшості видів протягом џвітіння змінюється забарвленням стерильних квіток. На початку весни вони зелені, потім світлішають і набувають забарвлення зелено-білого чи білого (H. cinerea Small.), згодом змінюючи відтінки на рожеві (H. paniculata 'Grandiflora','Wim's Red'), проте фертильні квітки забарвлення не змінюють.

Забарвлення квіток також залежить від складу грунту, на якому росте кущ, - на кислих грунтах $(\rho \mathrm{H}=4-5)$ квітки блакитні, на нейтральних або вапняних $(\rho \mathrm{H}=6-8)$ рожеві, а при закінченні вегетаџійного періоду набувають коричневого відтінку (H. arborescens, H. macrofilla). Всі види Hydrangeа в період џвітіння мають високий бал $\left(\mathrm{A}_{3}=5\right)$. У H. petiolaris, в умовах НДП «Софіївка», џвітіння було відсутнє, оскільки рослина не досягла генеративного віку. Перших декілька років вона росте повільно і як правило не квітує (Voronova, 2016).

У період плодоношення, плоди видів Hydrangea малопомітні і декоративного вигляду не мають, тому оџінені нами в один бал $\left(\mathrm{A}_{4}=1\right)$.

$\mathrm{Y}$ зимовий період декоративності рослинам надає забарвлення та фактура кори, пагонів та гілок. За фактурою кора у гортензій трішинувата, як (H. quercifolia). Дуже мальовнича фактура пагонів, яка підкреслюється рельєфною корою, вигинами, трішинами, на яких утворюються повітряні корені, завдяки яким рослина утримується на опорах (H. petiolaris). Забарвлення кори у представників видів Hydrangea коричневе, буро-коричневе оџінене нами в чотири бали $\left(\mathrm{A}_{5}=4\right)$. Отримані дані дають можливість спостерігати за шорічною динамікою декоративності представників видів Hydrangea (рис.)

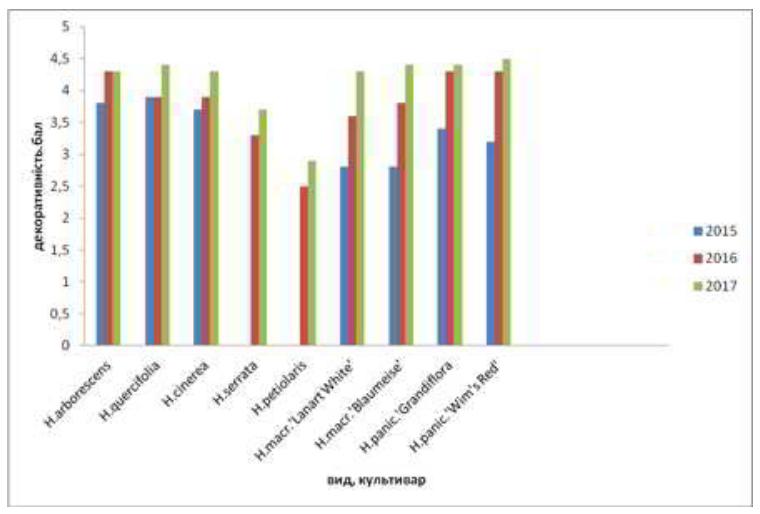

Рисунок. Динаміка декоративності представників видів роду Hydrangea

Figure. Dynamics of decorative elements of the genus $H y d r a n g e a$

За шомісячними даними можливо вирахувати загальний показник декоративності. Після обрахунків та побудови графіку динаміки декоративності представників роду Hydrangea, ми вираховували загальний показник декоративності, який є сумою загальної оџінки в балах за кожен місяџь досліджуваних років і позначається в умовних одиниџях. Кількісні показники декоративності переводили в 5-бальну шкалу наступним чином: при показникові 10-20 ум. од 3 бали; при 21-40 ум. од. - 4 бали; а при 41 ум. од. і більше -5 балів. Після всіх обрахунків отримали загальний показник декоративності роду Hydrangea (табл.).

\section{Висновок/Conclusion}

1. Біологічною особливістю представників роду Hydrangea, в умовах Правобережного ᄉісостепу України, є зміна декоративності впродовж періоду вегетаџї.

2. Найвищу декоративність види $H y d r a n g e a$ мають в період квітування з червня до жовтня $\left(\mathrm{A}_{3}=5\right)$ та в період повного облиствлення $\left(\mathrm{A}_{2}=5\right)$.

3. 3 усіх досліджуваних таксонів, в літньо-осінній період найвишими показниками декоративності характеризуються види: $H$. quercifolia, H. paniculata 'Grandiflora', 'Wim's Red', H. macrophylla 'Lanarth White'.

4. Всі досліджувані види є високодекоративними рослинами і загальний бал декоративності становить 4. 
5. Завдяки високим декоративним властивостям, рослини досліджуваних видів можна використовувати у садово-паркових насадженнях, ландшафтних композиџіях, моносадах, групових насадженнях, живоплотах, для декораџї̈ берегів водойм і зміџнення схилів, а також, як грунтопокривні рослини під кронами дерев.

Таблиџя. Загальна декоративність представників роду Hydrangea

Table. The general decorative nature of the genus $H y d r a n g e a$

\begin{tabular}{|l|c|c|}
\hline \multicolumn{1}{|c|}{ Вид/Species } & ум. од. /Standard units & $\begin{array}{c}\text { Декоративність, бал } \\
\text { Decorative, points }\end{array}$ \\
\hline Hydrangea arborescens L & 37.0 & 4 \\
\hline Hydrangea macrophylla 'Lanarth White' & 34.7 & 4 \\
\hline Hydrangea macrophylla 'Blaumeise' & 38.4 & 4 \\
\hline Hydrangea quercifolia Bartr. & 38.0 & 4 \\
\hline Hydrangea paniculata 'Grandiflora' & 38.2 & 4 \\
\hline Hydrangea paniculata 'Wim's Red' & 38.5 & 4 \\
\hline Hydrangea cinerea & 36.6 & 4 \\
\hline Hydrangea serrata & 28.0 & 4 \\
\hline Hydrangea petiolaris Sieb.et Zucc. & 34.3 & 4 \\
\hline
\end{tabular}

\section{Список посилань/References}

Fomyn, E. M. (1969) Hortenzyia. Moskva: Kolos, 40 p. (in Russian).

Gromadin, A. V. (2009) Dendrologija: uchebnik. Matjuhin, D. K. Moskva. Akademija, 240 p.(in Russian).

Korkulenko, O. M. (2012) Bioekolohichni osoblyvosti vydiv rodu Hydrangea L. ta perspektyvy ikh vykorystannia v ozelenenni m. Kyieva Tekst: avtoref. dys... kand. s.-h. nauk: 06.03.01 Kabinet Ministriv Ukrainy, Nats. un-t bioresursiv i pryrodokorystuvannia Ukrainy. K., 22 p. (in Ukrainian).

Kotelova, N. V., (1974) Vynohradova, O. N. Otsenka dekoratyvnosty derev'ev \& kustarnykov po sezonam hoda. Fyzyolohyia \& selektsyia rastenyy y ozelenenye horodov. 51p. (in Russian).

N.A. Kokhno \& dr. (1987) Kataloh derevev \& kustarnykov botanycheskykh sadov Ukraysskoi SSR. Kyev.: Naukova Dumka, 72 p. (in Russian).

Muzyka, H. I. (2002) Vytki zhymolosti. Uman': Umans'kyj dendropark “Sofivka”, 144 p. (in Ukrainian).

Taran, I. V., Agapova, A. M. (1981) Pejzazhnye gruppy dlja rekracionnogo stroitel'stva. Novosibirsk: Nauka. 240 p. (in Russian).

Miller, Renee. "Characteristics of the Hydrangeaceae Plant Family." Home Guides. SF Gate, URL: http:// homeguides. sfgate. com/characteristics-hydrangeaceae-plant-family. (Accessed 18 September 2018).

Voronova, N. O., Savvat'eva, Y. A., Smyrnova, T. V., Shevyreva, N. A. (2016) Hortenzyy: Vydy y sorta dlia rossyjskykh sadov. Moskva.: Fyton XXI,. 64.: yl. (in Russian). 